\section{Re: Overdreven tro på selvmordsrisikovurderinger?}

I et debattinnlegg i Tidsskriftet skriver J. Hagen og medarbeidere om selvmordsrisikovurderinger (1). Suicidal atferd har mange årsaker, men psykisk lidelse spiller svært ofte en sentral rolle. Derfor blir psykisk helsevern vårt viktigste redskap for å forebygge selvmord. En viktig forutsetning er imidlertid at helsepersonellet har tilstrekkelig kompetanse, blant annet til å vurdere selvmordsrisiko og iverksette adekvate intervensjoner. Dette var et av målene i de nasjonale retningslinjene for forebygging av selvmord i psykisk helsevern da de ble utgitt av Helsedirektoratet i 2008 (2). I sitt debattinnlegg i Tidsskriftet reiser imidlertid Hagen og medforfattere tvil om verdien av denne typen tiltak (1), og mener endog at retningslinjene kan «være uheldige for praksisfeltet, da de bidrar til å gi fagfolk og andre en overdreven tro på nytten av risikovurderinger». Dette mener vi er en sterk påstand uten empirisk grunnlag fra forskere som ellers bygger sin argumentasjon på å påpeke svakheter i det empiriske fundamentet for gjeldende retningslinjer og praksis.

Det er helt korrekt, som Hagen og medarbeidere påpeker, at det er vanskelig å forutsi selvmordsrisiko hos den enkelte pasient og at man bør være tilbakeholden med å stole for mye på slike vurderinger alene. Rasjonalet for å styrke kvaliteten på selvmordsrisikovurderinger - og alle andre aspekter ved pasientsikkerheten i psykisk helsevern - er heller ikke først og fremst å eliminere all risiko for den enkelte. Det ville være umulig og trolig også uetisk. Hensikten er å øke sikkerheten og kvaliteten for alle pasientene gjennom spesifikke og målrettede tiltak. Fra andre sektorer i samfunnet, for eksempel i veitrafikken, vet vi at det å skape sikrere miljø redder liv, selv om det er vanskelig å forutsi hvilke liv vi faktisk redder. Selvmord har i likhet med trafikkdødsfall mange årsaker som er virksomme både $\mathrm{i}$ enkeltpersonen og i miljøet.

Hagen og medarbeidere refererer også til et sett med såkalte myter om selvmordsrisikovurdering, og blant disse har de nevnt følgende: «Å rette oppmerksomhet mot risikofaktorer vil føre til lavere selvmordsrate». Dette er ingen myte, men en antakelse som av etiske, metodiske og økonomiske årsaker er vanskelig både å få bekreftet og avkreftet. Om forskningen på risikofaktorer for suicidal atferd vil bringe oss nærmere målet om å forebygge selvmord, vet vi ikke. Som klinikere med daglig kontakt med suicidale pasienter er imidlertid vår klare erfaring at kvalifisert årvåkenhet overfor risikofaktorer og evne til å bruke den i planlegging av behandling og i samspill med pasienten er av uvurderlig betydning.

Bekjempelse av myter om selvmord er viktig og har en historie i Norge fra Nils Retterstøls pionerinnsats i 1970-årene. Vi frykter at Hagen og medarbeideres innlegg dessverre ikke vil bidra til å redusere faktiske myter.

\section{Lars Mehlum \\ lars.mehlum@medisin.uio.no \\ Ewa Ness \\ Fredrik A. Walby}

Lars Mehlum (f. 1956) er spesialist i psykiatri og professor ved Nasjonalt senter for selvmordsforskning og -forebygging.

Ingen oppgitte interessekonflikter.

Ewa Ness (f. 1958) er spesialist i psykiatri og fagsjef ved Klinikk psykisk helse og avhengighet, Oslo universitetssykehus.

Ingen oppgitte interessekonflikter.

Fredrik A. Walby (f. 1970) er sjefpsykolog ved Diakonhjemmet sykehus. Ingen oppgitte interessekonflikter.

\section{Litteratur}

1. Hagen J, Hjelmeland H, Knizek BL. Overdreven tro på selvmordsrisikovurderinger? Tidsskr Nor Legeforen 2014; 134: 394

2. Nasjonal faglig retningslinje for forebygging av selvmord i psykisk helsevern http://helsedirektoratet.no/publikasjoner/nasjonal-faglig-retningslinje-forforebygging-av-selvmord-i-psykisk-helsevern/Sider/default.aspx (14.2.2014)

\section{Re: Overdreven tro på selvmordsrisikovurdering?}

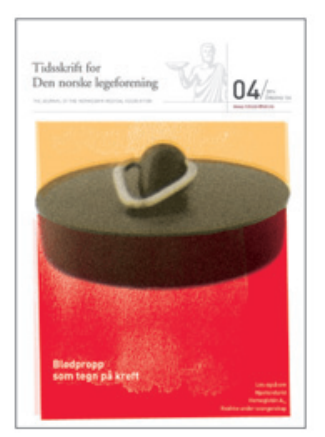

God kartlegging av risiko for suicid, og tiltak der risikoen anses å være stor, er selvsagt verdifullt og viktig. Som vi vet kan ambivalensen rundt å velge livet være der, også hos dem vi vurderer å ha lav risiko. Vi kan hjelpe og gi råd. Likevel vil våre pasienter kunne velge selvmord som løsning på sitt indre strev.

I sin kommentar til artikkelen Overdreven tro på selvmordsrisikovurdering?

skriver Lars Mehlum: «Fra andre sektorer i samfunnet, for eksempel i veitrafikken, vet vi at det å skape sikrere miljø redder liv, selv om det er vanskelig å forutsi hvilke liv vi faktisk redder. Selvmord har i likhet med trafikkdødsfall mange årsaker som er virksomme både i enkeltpersonen og i miljøet.» (1)

Jeg synes dette er en viktig og riktig vinkling for å bli bedre i stand til å hjelpe unge og voksne vekk fra selvmord. Trafikkens veimidtdeler, flere filer i fartsretninger, gode på- og avkjøringsfelter, rundkjøringer, fartsreduserende tiltak, god belysning og trafikkopplæring i skolen er noe av det som virker (2). Snublende nær metaforer for forebyggende psykisk helsearbeid?

Som barne- og ungdomspsykiater ser jeg nytten av gode helsesøstre, lyttende fastleger som ser hele mennesket, kompetente rådgivere, sosiallærere og pedagoger i skolen, lavterskeltilbud for foreldre som ser at deres barn og ungdommer strever og ønsker å bli mer kompetente voksne, tidlig samarbeid mellom barnevern, politi og helsevesen når unge ruser seg m.m.

Jeg skal fortsette å kartlegge og vurdere risiko - det er en del av mitt ansvar som lege i BUP. Kanskje jeg også kan være til hjelp og støtte for noen av dem jeg møter i mitt arbeid. Samtidig ønsker jeg mer søkelys på det som gir mennesker i alle aldre mot og lyst til å velge livet. Da snakker jeg om opplevelsen av å ha verdi og å høre til - der ute. Det er et samfunnsansvar, ikke noe vi styrer fra en sykehusavdeling eller poliklinikk.

Jeg tror helhetlig tenkning og samarbeid mellom helse og skole/ arbeidsliv kan gi stor gevinst. Veien fra dårlig psykisk helse til suicid er oftest lang, og lidelse hos den enkelte har ofte store medmenneskelige og økonomiske konsekvenser underveis.

Regnestykket synes enkelt, men politikere velger visst å se en annen vei? Det vil alltid være noen som velger å avslutte livet sitt, uansett hva vi gjør, som med trafikkulykker. Men alternativene må være mer synlige og «godt markert».

\section{Eli Regine Emblemsvåg}

eliregine.emblemsvag@vestreviken.no

Eli Regine Emblemsvåg (f. 1958) er overlege og spesialist i barne-
og ungdomspsykiatri BUPA, Asker BUP.
Ingen oppgitte interessekonflikter.

Litteratur

1. Hagen J, Hjelmeland H, Knizek BL. Overdreven tro på selvmordsrisikovurderinger? Tidsskr Nor Legeforen 2014; 134: 394

2. http://vegvesen.no/_attachment/130037/binary/302637?fast_title= Nasjonal+tiltaksplan+for+trafikksikkerhet+2010-2013.pdf

\section{J. Hagen og medarbeidere svarer:}

Nasjonale retningslinjer for forebygging av selvmord i psykisk helsevern (1) har gode intensjoner og har sannsynligvis bidratt til økt kunnskap og bevissthet om selvmordsproblematikk.

Vårt hovedbudskap er imidlertid at retningslinjenes søkelys på risikofaktorer og standardiserte risikovurderinger kan ha hatt uheldige og utilsiktede konsekvenser for praksisfeltet. Grunnlaget for vårt synspunkt er klinisk erfaring og innspill fra helsepersonell 